\title{
Unusually high frequency of cross-pollination between rice landraces Shiuli and Kharah with coincident flower-opening times
}

\author{
Debal Deb* and D. Bhattacharya \\ Centre for Interdisciplinary Studies, 186A Kalikapur Canal Road, Kolkata 700 099, India
}

\begin{abstract}
Cross-pollination in cultivated rice (Oryza sativa L.) is rarely reported to exceed $2 \%$. This low crosspollination frequency (CPF) is conducive to successfully maintaining the purity of rice landraces for many generations. We were therefore surprised to notice a dramatic loss of genetic purity in some of the pure line landraces in many farmers' fields. Having ruled out the possibility of mixing of seeds from different varieties, we surmised this rapid loss of genetic purity to be due to a somewhat higher degree of crosspollination, and conducted a carefully designed experiment with suitably chosen pairs of landraces. We report here an unusually high $(>81 \%) \mathrm{CPF}$ seen in a pair of landraces whose flower opening times (FOTs) were coincident. Our control experiment on a pair of landraces with non-overlapping FOTs failed to detect any cross-pollination. This preliminary report suggests that the crucial importance of FOT diversity in landraces in determining CPF has not been recognized in designs of previous reports of crossing experiments, resulting in a severe underestimation of CPF in cultivated rice under natural conditions.
\end{abstract}

Keywords: Cross-pollination frequency, flower opening and closing times, genetic purity, pollen viability, rice landraces.

THE available literature over the past 100 years indicates that cross pollination frequency $(\mathrm{CPF})$ in rice rarely exceeds $2 \%$ (refs 1-13). While the frequency of gene flow to wild rice may be $10 \%$ or higher ${ }^{14-16}$, most of the experiments with cultivated rice varieties have reported CPF to lie below $1 \%$. Only one study reported $3 \% \mathrm{CPF}$ (ref. 8), and Somaratne et al. ${ }^{9}$ reported a Sri Lankan cultivar Bg 379-2 showing 'a potential out-crossing rate of $3.41 \%$ and an average out-crossing rate of $1.29 \%$ using dominant morphological markers'. Rice research published in Chinese, Japanese and Korean languages also do not mention, to the best of our knowledge, any high CPF in rice landraces in natural conditions (see endnote 1), except for a study by Bae et al. ${ }^{13}$ which recorded over $9 \%$ $\mathrm{CPF}$ in one instance from a transgenic rice to Nakdongbyeo, a japonica cultivar. Nevertheless, 'in the field con-

\footnotetext{
*For correspondence. (e-mail: debdebal@gmail.com)
}

dition', the authors noted, 'rice out-crossing rate was less than 1\%' (ref. 13). Extremely low CPF for cultivated conventional rice repeatedly appears in the review literature $^{17}$ and official records ${ }^{18}$. However, our own field experience over the past 25 years, growing over 1000 rice varieties each year, seems to be dissonant with this received wisdom.

On our conservation farm, where we grow more than 1400 rice varieties every year, any chance of crosspollination is precluded by following the 'flowering asynchrony' method - planting all landraces in different plots in a manner that no neighbouring varieties share the same date of anthesis and $50 \%$ flowering ${ }^{19}$. We distribute the seeds of these landraces to farmers from Vrihi (http://cintdis.org/vrihi) seed bank (see endnote 2). Furthermore, any 'off type' plant, arising from chance mutations detected in any plant part is rouged out in every growing season, to maintain genetic purity of each germ line. Most of these landraces are also maintained by a majority of recipient farmers without any loss of purity. However, for a small number of landraces (about 100 out of 1400) distributed among farmers, we noticed that $>10 \%$ grains showed distinctly different characters from those of the original samples. Further inquiries and observations on these farms indicated that these specific landrace samples had lost a few of their key morphological characters over a few years, implying accumulation of genetic impurities over seasons of cultivation of the pure lines. This happened in a few landraces, even when the farmers carefully prevented physical mixing of grains from different cultivars during threshing and milling, and at the time of sowing. The only possible means of loss of genetic purity in the pure lines of landraces distributed from Vrihi is cross-pollination with different cultivars grown in adjacent field plots. The conventional wisdom, substantiated by the literature, of extremely low CPF (Table 1) cannot explain our two-decade long observation of wide disparity of key characters between the samples of a number of rice landraces distributed to farmers and the samples returned in subsequent years by those farmers.

To examine the extent of cross-pollination in rice under field conditions, we set up an experiment with two pairs of rice landraces. Our results provide satisfactory explanation for both the contradictory observations, viz. 
why rice is reported to be almost entirely self-pollinated and conditions under which an unusually high frequency of cross-pollination is possible.

\section{Materials and methods}

\section{Study site and seasons}

The experiment was conducted at Basudha conservation farm $\left(19^{\circ} 42^{\prime} 32.0^{\prime \prime} \mathrm{N}, 83^{\circ} 28^{\prime} 8.4^{\prime \prime} \mathrm{E}\right)$, Rayagada district, Odisha, India, in the aman season (June-December) of 2018 and 2019.

\section{Rice landraces}

Amongst the landraces in which we had frequently noticed loss of genetic purity, we selected pure lines of Shiuli and Basanti churi varieties, with which we paired two other pure line landraces, namely Kharah and Bhalu dubraj for our experiment. These landraces shared similar floral traits, namely full panicle exsertion, extrusion of long stamens within 3-5 sec after floret opening, and non-extruded stigmata. Pure line seeds of these landraces were taken from Vrihi's accession, planted in two plots as two discrete pairs (Bhalu dubraj and Basanti churi as a first pair, Kharah and Shiuli as the second pair), based on identical dates of anthesis and contradistinguishable morphological characters.

In plot 1 , Bhalu dubraj was chosen as the pollen parent (PP), with distinctive purple leaf margins and long $(>60$ $\mathrm{mm}$ ) awns throughout the length of panicle, while Basanti churi was the ovary parent (OP), with entirely green leaves, purple nodes and no awn. In plot 2, Kharah was chosen as the PP characterized by purple leaves, purple nodes, short awns in the apical quarter of the length of panicle, in contrast to the entirely green leaves, green nodes and no awn in Shiuli, the OP. Table 2 provides a summary of the morphological characters of the chosen

Table 1. Cross-pollination frequency in rice (Oryza sativa) reported in the literature

\begin{tabular}{lccc}
\hline Pollen parent & Ovary parent & $\begin{array}{c}\text { Highest } \\
\text { frequency }(\%)\end{array}$ & Reference \\
\hline Conventional rice & Conventional rice & 0.04 & 1 \\
& & 0.82 & 2 \\
& & 0.89 & 3 \\
& & 1 & 4,5 \\
Transgenic rice & Conventional rice & 1.23 & 6 \\
& & 1.89 & 7 \\
& & 3.0 & 8 \\
& & 3.41 & 9 \\
& & 0.086 & 10 \\
& & 9.1 & 11 \\
\hline
\end{tabular}

landraces and the respective dates of $50 \%$ anthesis during the aman season of cultivation.

Following the character codes depicted in Table 2, the morphotype of OP of the first pair was LOF2N1A0H3, while that in the second pair was L0F3N0A0H3. Detection of any variation in these traits in the F1 progeny of either OP would unmistakably indicate the transfer of genes from the respective PP. Since each pollination event is independent, the F1 progeny would consist of a mix of different characters in different proportions in the progeny.

\section{Experimental design}

To obviate the effects of wind speed and direction, a single OP was planted in each experimental plot along with a population of 48 PPs, all planted on 8 July 2018, in a $7 \times 7$ matrix with $25 \mathrm{~cm} \times 25 \mathrm{~cm}$ spacing. The objective of the experiment was to measure the extent of crosspollination under field conditions, so the planting design was different from those of earlier studies. A multitude of PPs on all sides were planted $25 \mathrm{~cm}$ apart to ensure crosspollination of the centrally placed single OP in each plot from any side, regardless of wind-blowing direction (Figure 1). At the booting stage, the experimental land was screened with a thin polyvinyl screen on all sides to prevent accidental influx of pollen from other cultivars in flowering outside the boundary. No barrier was put between the two plots, because all flowers of the plants in plot 1 had closed seven days before the opening of flowers of plants in plot 2 .

The experiment spanned two seasons. Seeds of all the landraces selected for the experiment were sown in June 2018. In December 2018, the seeds from each OP were harvested. In June 2019, all these seeds were sown in nursery beds for germination. All viable seedlings were transplanted in July 2019, and each plant was assessed for morphological characters to detect the extent of crosspollination.

\begin{tabular}{|c|c|c|c|c|c|c|c|c|c|c|c|c|c|}
\hline (a) & & & Plot & & & & (b) & & & lot & & & \\
\hline b & b & b & $\mathbf{b}$ & b & b & $\mathbf{b}$ & $\mathrm{K}$ & $\mathrm{K}$ & $\mathrm{K}$ & $\mathrm{K}$ & $\mathrm{K}$ & $\mathrm{K}$ & K \\
\hline b & $\mathbf{b}$ & b & b & $\mathbf{b}$ & b & $\mathbf{b}$ & K & K & K & $\mathbf{K}$ & K & K & K \\
\hline b & b & b & b & b & b & b & $\mathrm{K}$ & K & K & $\mathbf{K}$ & K & $\mathbf{K}$ & K \\
\hline b & $\mathbf{b}$ & b & $\mathbf{B}$ & $\mathbf{b}$ & $\mathbf{b}$ & b & K & $\mathbf{K}$ & $\mathrm{K}$ & $\mathbf{s}$ & $\mathbf{K}$ & $\mathbf{K}$ & $\mathbf{K}$ \\
\hline b & b & b & b & b & b & b & $\mathrm{K}$ & K & K & K & K & $\mathrm{K}$ & $\mathbf{K}$ \\
\hline b & b & b & $\mathbf{b}$ & b & $\mathbf{b}$ & $\mathbf{b}$ & K & K & $\mathbf{K}$ & $\mathbf{K}$ & $\mathbf{K}$ & $\mathbf{K}$ & $\mathbf{K}$ \\
\hline b & b & b & b & b & b & b & K & K & K & K & K & K & K \\
\hline
\end{tabular}

Figure 1. Planting design: Basanti churi (B) and Shiuli (S) are the ovary parents, placed in plot $1(\boldsymbol{a})$ and plot $2(\boldsymbol{b})$, amid the respective pollen parents Bhalu dubraj (b) and Kharah $(\mathrm{K})$ in a $7 \times 7$ square matrix, spaced at $25 \mathrm{~cm}$ between each pair of plants. 
RESEARCH ARTICLES

Table 2. Distinguishing descriptors of rice landraces selected as morphological markers in the cross-pollination experiment

\begin{tabular}{|c|c|c|c|c|c|}
\hline & & \multicolumn{2}{|c|}{ Plot 1} & \multicolumn{2}{|l|}{ Plot 2} \\
\hline \multicolumn{2}{|c|}{ Landrace } & Bhalu dubraj & Basanti churi & Kharah & Shiuli \\
\hline Descriptor & Descriptor code & Pollen parent & Ovary parent & Pollen parent & Ovary parent \\
\hline $50 \%$ Flowering date & & 1 October & 1 October & 18 October & 18 October \\
\hline Leaf colour & $\mathrm{L}$ & Purple margin (1) & Green $(0)$ & Entire leaf purple (2) & Green $(0)$ \\
\hline Flag leaf attitude & $\mathrm{F}$ & Semi-erect (2) & Semi-erect (2) & Semi-erect (2) & Horizontal (3) \\
\hline Node colour & $\mathrm{N}$ & Green $(0)$ & Light purple (1) & Purple (2) & Green $(0)$ \\
\hline Awn distribution & A & Entire panicle (5) & No awn $(0)$ & Apical quarter of panicle (2) & No awn $(0)$ \\
\hline $\begin{array}{l}\text { Longest awn length } \\
\quad(\mathrm{mm})\end{array}$ & & 62.0 & 0 & 11.0 & 0 \\
\hline Hull colour & $\mathrm{H}$ & Straw (2) & Gold furrows (3) & Straw (2) & Gold furrows (3) \\
\hline
\end{tabular}

Numbers in parentheses are the scaled values of characters, following Bioversity International ${ }^{23}$ descriptor codes. $^{2}$

Table 3. Details of flower opening times (FOT) and flower closing times (FCT) of rice landraces and weather on those dates

\begin{tabular}{|c|c|c|c|c|c|c|c|c|}
\hline $\begin{array}{l}\text { Experimental } \\
\text { plot no. }\end{array}$ & Landrace & $\begin{array}{l}\text { Florets opening/ } \\
\text { closing }\end{array}$ & Date and time & $\begin{array}{l}\text { Floret opening } \\
\text { duration (min) }\end{array}$ & $\begin{array}{c}\text { Temperature } \\
\text { maximum }\left({ }^{\circ} \mathrm{C}\right)\end{array}$ & $\begin{array}{l}\text { Temperature } \\
\text { minimum }\left({ }^{\circ} \mathrm{C}\right)\end{array}$ & $\begin{array}{l}\text { Rainfall } \\
(\mathrm{mm})\end{array}$ & $\begin{array}{c}\text { Rain } \\
\text { duration }\end{array}$ \\
\hline \multirow[t]{4}{*}{1} & \multirow[t]{2}{*}{$\begin{array}{l}\text { Basanti Churi } \\
\text { (ovary parent) }\end{array}$} & FOT of first florets & $\begin{array}{l}29 \text { September } 2018 \\
11: 09 \text { am }\end{array}$ & 53 & 30 & 25 & 0.0 & - \\
\hline & & FCT of last florets & $\begin{array}{l}6 \text { October } 2018 \\
12: 02 \mathrm{pm}\end{array}$ & & 31 & 24 & 0.0 & - \\
\hline & \multirow[t]{2}{*}{$\begin{array}{l}\text { Bhalu dubraj } \\
\text { (pollen parent) }\end{array}$} & FOT of first florets & $\begin{array}{l}29 \text { September } 2018 \\
\text { 10:06 am }\end{array}$ & 73 & 30 & 25 & 0.0 & - \\
\hline & & FCT of last florets & $\begin{array}{l}5 \text { October } 2018 \\
11: 19 \text { am }\end{array}$ & & 30 & 25 & 14.9 & $2: 10-5: 50 \mathrm{pm}$ \\
\hline \multirow[t]{4}{*}{2} & \multirow[t]{2}{*}{$\begin{array}{l}\text { Shiuli } \\
\text { (ovary parent) }\end{array}$} & FOT of first florets & $\begin{array}{l}15 \text { October } 2018 \\
09: 38 \mathrm{am}\end{array}$ & 106 & 30 & 26 & 0.0 & - \\
\hline & & FCT of last florets & $\begin{array}{l}22 \text { October } 2018 \\
11: 24 \mathrm{am}\end{array}$ & & 33 & 24 & 0.0 & - \\
\hline & \multirow[t]{2}{*}{$\begin{array}{l}\text { Kharah } \\
\text { (pollen parent) }\end{array}$} & FOT of first florets & $\begin{array}{l}14 \text { October } 2018 \\
9: 43 \text { am }\end{array}$ & 80 & 30 & 26 & 0.0 & - \\
\hline & & FCT of last florets & $\begin{array}{l}21 \text { October } 2018 \\
11: 17 \mathrm{am}\end{array}$ & & 32 & 25 & 0 & - \\
\hline
\end{tabular}

\section{Measurements of flower opening time, flower closing time and stamens}

The booting and approximate dates of 50\% flowering of each landrace were known from our previous records of cultivation. At the approach of the booting date of each landrace, we examined the panicles to surmise the date of panicle emergence and opening of the first florets. At the onset of panicle emergence, one of two workers stood at each of the plots nos 1 and 2 in the morning, starting at $8: 30 \mathrm{am}$, and waited until the first floret of each cultivar opened. We recorded this time as the flower opening time (FOT) of that variety, and also recorded the closing time of the same floret on a cellphone timer. On the following days, one of two workers stood before the same panicle in the same plot to record FOT of the florets below the apical florets down the panicle. We repeated this procedure until the last few florets near the base of the panicle opened, and recorded the flower closing time (FCT). The time interval from FOT of the first floret of the first emerged panicle to FCT of the last floret on the same panicle (in the case of OPs), or on the panicle that emerged last (in the case of multiple panicles of PPs) denoted the maximum duration of opening of florets of the cultivar.

To detect any relationship between stamen length and duration of opening of florets, we measured the length of stamens of each variety, using the mobile phone application Magnifier Plus (version 4.4.1), calibrated to millimetre scale.

\section{Weather recordings}

Maximum and minimum temperatures were recorded using a thermometer kept in the farm house about $30 \mathrm{~m}$ from the experimental plots. Rainfall data were recorded daily using a standard rain gauge kept in the farmyard.

\section{Results and discussion}

The date and time of FOT of the first florets and FCT of the last florets of all the cultivars, and weather data on the corresponding dates are given in Table 3, which shows 
Table 4. Distribution of characters among the progeny of Shiuli in plot $2(N=92)$

\begin{tabular}{lccc}
\hline Character transmitted via pollen & \multicolumn{2}{c}{$\begin{array}{c}\text { No. of plants } \\
\text { inheriting the character }\end{array}$} & Frequency \\
\hline Purple leaf & L2 & 17 & 0.185 \\
Purple node & $\mathrm{N} 2$ & 33 & 0.359 \\
Semi-erect flag leaf & $\mathrm{F} 2$ & 55 & 0.598 \\
Straw hull colour & $\mathrm{H} 2$ & 49 & 0.533 \\
Awns in apical quarter of panicle & $\mathrm{A} 2$ & 2 & 0.022 \\
Awns in tip of panicle & A1 & 7 & 0.076 \\
All characters identical to ovary parent Shiuli (S) & L0N0F3H3A0 & 17 & 0.185 \\
All characters identical to pollen parent Kharah & L2N2F2H2A2 & 1 & 0.011 \\
\hline
\end{tabular}

that day temperatures were identical for both pairs of parents during the experiment, and the range of temperatures during the flowering period $\left(24^{\circ}-30^{\circ} \mathrm{C}\right)$ did not imply either heat $\left(>35^{\circ} \mathrm{C}\right)$ or cold $\left(<14^{\circ} \mathrm{C}\right)$ stress for the rice plants. Most of the days during the flowering of each landrace were sunny, except a spell of rain on 6 October 2018. Precipitation occurred about $3 \mathrm{~h}$ after the FCT of Bhalu dubraj; so floral biology and pollen release were unaffected by rainfall and clouds, which are normal for the entire aman season in India.

Table 3 further shows that the florets of Basanti churi, OP in plot 1, opened $63 \mathrm{~min}$ after FOT (and anther dehiscence) of Bhalu dubraj, and closed $53 \mathrm{~min}$ thereafter, every day from 29 September to 6 October 2018. In plot 2 , Shiuli's first florets had opened about $5 \mathrm{~min}$ before the opening of the first florets of PP and closed $106 \mathrm{~min}$ thereafter. The length of stamens of the four landraces was approximately the same, and had no detectable association with either FOT, or the maximum duration of florets remaining open.

The progeny of Basanti churi, OP in plot 1, comprised of 96 seedlings germinated from 105 grains from the PP. This progeny did not show any character deviant from the OP Basanti churi, and none of the distinctive characters of the PP Bhalu dubraj (purple leaf margin, awns, green node) was seen, indicating $100 \%$ self-pollination.

The progeny of Shiuli, OP in plot 2, comprised of $N=92$ seedlings successfully germinated from 102 grains, among which $S=17$ plants were identical to OP, while the rest (75) of the progeny showed one or more characters inherited from Kharah, the PP. The morphological characters of this progeny that were deviant from OP in plot 2 were: purple leaf (coded here as L2), purple node (coded N2), semi-erect flag leaf (coded F2), awns in apical quarter of the panicle (A2) and hull colour (H2) all characteristic of PP. An additional character, 'awns in the tip of panicle' (A1), absent in both parents, was also recorded in seven individuals and seems to be a variant of A2, inherited from Kharah. Table 4 shows the distribution of characters expressed in this progeny.

The frequency of inheritance of all characters from Shiuli, the OP ('no transmission' of any character from PP) was $S / N=0.185$. This is the frequency of self- pollination in the florets of Shiuli. Therefore, the overall frequency of pollen mediated transmission of at least one character from PP is $(1-S / N)=0.815$, which is several orders of magnitude higher than the CPF values in rice reported in the literature. The $95 \%$ confidence interval was $(0.736-0.894)$ and the $99 \%$ confidence interval was (0.727-0.903), indicating that even the lower limit of the $99 \%$ confidence interval exceeds $72 \%$. In contrast, the progeny of Basanti churi, the OP in plot 1, showed zero cross-pollination, corroborating earlier reports of CPF. We have also gathered molecular evidence of the inheritance of DNA segments (such as the SSR marker Rm171) from $P P$ in each of the offspring that inherited at least one distinctive morphological character of the former.

The only possible reason for the enormous difference between the results of all previous experiments by other researchers and that of the plot 2 progeny in the present experiment seems to be the proximity of FOTs of the two cultivars. Rice pollen loses its viability within 5 min of shedding, although stigmata remain receptive for about three days ${ }^{21}$. If a floret of OP opens more than 5 min after anther emergence of PP, the ovary of OP is unlikely to receive any viable pollen. On opening, the rice florets close after a period of $25 \mathrm{~min}$ or longer, never to open again; so the same florets with non-extruding stigma can never receive any new batch of pollen after their first day of opening. Thus, the ovary of OP would receive pollen shed from the anthers of a neighbouring PP, if and only if the FOTs of both OP and PP are close in time. If florets of both OP and PP open at the same time, the chance of successful cross-pollination is very high. (The chance will always be less than $100 \%$, because OP's own pollen from its own floret(s) will be shed on its stigma at a higher density than the 'alien' pollen.) The FOTs of both parental lines in plot 2 almost entirely overlapped; most importantly, the OP florets had already opened at 9:38 am, $5 \mathrm{~min}$ before the opening of PP (9:43 am), thus allowing cross-pollination of most of the florets of OP as soon as the grains of PP pollen were released. Since all the florets of OP opened everyday at about the same time, each of its florets was exposed to the pollen flown from the florets of PPs, which also opened everyday about 5 min after the FOT of OP. 
By contrast, in plot 1, FOT of florets of OP opened more than an hour after the FOT of PP, which implies that no viable pollen would reach the stigmata of the OP, resulting in zero cross-pollination. This may well be the case for most of the previous reports of cross-pollination in cultivated rice $^{1-12}$.

\section{Conclusion}

The success of cross-pollination is crucially governed by the time of anther dehiscence, occurring within a few seconds after FOT, brief longevity of the pollen grains and duration of exposure of the stigma to pollen ${ }^{17,20}$. As the pollen viability is lost after 5 min (ref. 20), the FOT of OP occurring more than 5 min after the FOT of PP is certain to drastically obviate the chances of crosspollination. Also, cross-pollination is not possible if the florets of OP close before the entry of the 'non-self' pollen. Non-extruding stigmata of these landraces preclude the possibility of OP receiving pollen from PP anytime after the florets close. Thus, FOT overlap seems to be the only crucial determining factor in crosspollination success. Despite knowledge of a wide diversity in FOT among rice cultivars ${ }^{21,22}$, none of the previous studies of cross-pollination in rice has mentioned the FOTs of the cultivars examined. It is plausible that the previous researchers selected varietal pairs with the same date of anthesis, but widely different FOTs.

The observations of this study show that crosspollination is most certain if the OP florets remain open when the pollen grains of PP are released; conversely, pollen transfer may fail (e.g. between landraces in plot 1 in this experiment as well as in the studies cited in Table 1), if the florets of OP open more than $5 \mathrm{~min}$ after the release of pollen from the anthers of PP. While this factor appears sufficient to explain the high CPF in the second pair of landraces in plot 2 , and failed cross-pollination in the first pair of landraces in plot 1 in this experiment, further studies are needed to explore the contribution of other environmental factors, if any. Pollination events are of course influenced by various environmental factors. The combined effects of day temperature, photoperiod and humidity on the FOT of various rice genotypes 'remain unclear, particularly under field conditions, and this limits our ability to predict FOT ${ }^{22}$. However, the objective of the present study was not to check the variability of FOT with environmental vagaries. Rather, we checked CPF in two pairs of landraces under identical environmental conditions (Table 3). Using Occam's razor, we deem it unnecessary to assume that almost identical range of day temperatures, daylight duration, etc. in the same farm field in the same growing season radically increased CPF in one pair of varieties but not in the other.

In the light of these unique findings of very high degree of cross-pollination between two varieties with high FOT overlap (and the adequate preliminary control of no cross-pollination between varieties with little or no overlap), we have completed a set of more rigorous and quantitative experiments involving seven pairs of landraces with a range of FOT overlaps in the aman season of 2020, to explore the relationship of CPF with the delay of FOT of OP following that of PP. The progeny of each of the OPs from this set of experiments will be sown in the forthcoming aman season of 2021, to test the generality of our explanation based on FOT overlap, and we hope to find data to provide a more robust explanation. However, regardless of the accuracy of the causal explanation given here, and of any plausible environmental or physiological influences on $\mathrm{CPF}$, the unusually high $\mathrm{CPF}$ in cultivated rice reported in this study indicates that the normal range of $\mathrm{CPF}$ in cultivated rice under natural conditions is severely under-reported in all previous studies. We further suggest that knowledge of FOTs of the cultivars is of great importance, both for maintaining genetic purity of the vanishing landraces and to prevent undesired gene transfer from transgenic rice to cultivated rice populations.

\section{Endnote}

1. We are indebted to Dr Ga Lai Law (Tokyo, Japan) and Mr Rahul Vaswani and Ms Kim Haejung (Seoul, South Korea) who confirmed that such high frequencies of cross-pollination have not yet been reported to the best of their knowledge in the scientific literature in Japanese and Korean respectively.

2. We distribute the seeds of rare and endangered rice landraces to farmers from Vrihi, India's largest non-governmental folk rice seed bank, and the farmers return the same quantity of seeds from their harvest, thereby replenishing the seed stock of Vrihi for further distribution.

Competing interest statement: No competing interest.

1. Endo, T., Sato, H., Yamaguchi, M., Kataoka, T., Nakagomi, K., Ito, T. and Mori, K., Estimate of outcrossing rates in a rice plant (Oryza sativa L.) under field conditions using a purple grain rice cultivar, Okunomurasiki. Breed. Sci., 2009, 59, 195-202.

2. da Silva, E. F., da Silva, L. M. and Montalván, R., Crossing rate and distance in upland rice. Bragantia, 2005, 64(2), 197-201.

3. Reaño, R. and Pham, J. L., Does cross-pollination occur during seed regeneration at the International Rice Genebank? Intern. Rice Res. Notes, 1998, 23, 5-6.

4. Jodon, N. E., Occurrence and importance of natural crossing in rice. Rice J., 1959, 62(8), 8-10.

5. Robert, E. H., Craufurd, R. Q. and Cochet, F. L., Estimation of percentage of natural cross-pollination: experiment on rice. Nature, 1961, 190, 1084-1085.

6. Sahadevan, P. C. and Namboodiri, K. M. N., Natural crossing in rice. Proc. Indian Acad. Sci., Sect. B, 1963, 58, 176-185.

7. Beachell, H. M., Adair, C. R., Jodon, N. E., Davis, L. L. and Jones, J. W., Extent of natural crossing in rice. J. Am. Soc. Agron, 1938, 30, 743-653.

8. Coste, R., El Arroz: Colección Agricultura Tropical, Editorial Blume, Barcelona, Spain, 1969, 2nd edn, pp. 35-72.

9. Somaratne, L. H. M. Y. K., Abayawickrama, A. S. M. T., Wickramasinghe, I. P. and Samarasinghe, W. L. G., Estimating 
outcrossing rate of $\mathrm{Bg} 379-2$ using morphological markers and confirmation by molecular markers. Rice Sci., 2012, 19(2), 166168.

10. Messeguer, J., Fogher, C., Guiderdoni, E., Marfà, V., Català, M. M., Baldi, G. and Melé, E., Field assessments of gene flow from transgenic to cultivated rice Oryza sativa L. using a herbicide resistance gene as tracer marker. Theor. Appl. Genet., 2001, 103, 1151-1159.

11. Messeguer, J., Marfà, V., Català, M. M., Guiderdoni, E. and Melé, E. A., Field study of pollen-mediated gene flow from Mediterranean GM rice to conventional rice and the red rice weed. Mol. Breed., 2004, 13, 103-112.

12. Rong, J. et al., Dramatic reduction of crop-to-crop gene flow within a short distance from transgenic rice fields. New Phytol., 2007, 173, 346-353.

13. Bae, H.-K. et al., Evaluation of gene flow from GM to non-GM rice. Plant Breed. Biotech., 2013, 1(2), 162-170.

14. Langevin, S. A., Clay, K. and Grace, J. B., The incidence and effect of hybridization between cultivated rice and its related weed red rice (Oryza sativa L.). Evolution, 1990, 44, 1000-1008.

15. Song, Z. P., Lu, B.-R., Zhu, Y. G. and Chen, J. K., Gene flow from cultivated rice to the wild species Oryza rufipogon under experimental field conditions. New Phytol., 2003, 157, 657-665.

16. Wang, F. et al., A large-scale field study of transgene flow from cultivated rice (Oryza sativa) to common wild rice (O. rufipogon) and barnyard grass (Echinochloa crus-galli). Plant Biotechnol. J., 2006, 4, 667-676.

17. Moldenhauer, K. A. K. and Gibbons, J. H., Rice morphology and development. In Rice: Origin, History, Technology and Production (eds Smith, C. W. and Dilday, R. H.), Wiley, Hoboken, NJ, USA, 2003, pp. 103-127.

18. OGTR, The Biology and Ecology of Rice (Oryza sativa L.) in Australia, Office of the Gene Technology Regulator, Woden, Australia, 2005.
19. Deb, D., Flowering asynchrony can maintain genetic purity in rice landraces. Curr. Sci., 2006, 91, 155-157.

20. GoI, Biology of Oryza sativa L. (Rice), Department of Biotechnology, Ministry of Science and Technology, and Ministry of Environment and Forests, Government of India, 2011; http://biosafety.icar.gov.in/biologyof-oryza-sativa-l-rice

21. Kobayasi, K., Masui, H., Atsuta, Y., Matsui, T., Yoshimoto, M. and Hasegawa, T., Flower opening time in rice - cultivar difference and effect of weather factors. In Proceedings of MARCO Symposium 2009: challenges for Agro-Environmental Research in monsoon Asia, (CD-ROM), National Institute for AgroEnvironmental Sciences, Tsukuba, Japan, 2009.

22. Kobayasi, K., Matsui, T., Yoshimoto, M. and Hasegawa, T., Effects of temperature, solar radiation, and vapor-pressure deficit on flower opening time in rice. Plant Prod. Sci., 2010, 13(1), 2128.

23. Bioversity International, International Rice Res. Institute and the Africa Rice Center. Descriptors for Wild and Cultivated Rice (Oryza spp.) Bioversity International, Rome, Italy, 2007.

ACKNOWLEDGEMENTS. We thank Mahendra Nauri (Basudha) for assistance in recording characters of all the rice plants in the experiments, Prof. N. V. Joshi (Indian Institute of Science, Bengaluru) for encouragement and guidance in preparing the manuscript, and two anonymous reviewers for useful suggestions. This study received no institutional funding support.

Received 4 November 2020; revised accepted 17 March 2021

doi: $10.18520 / \mathrm{cs} / \mathrm{v} 121 / \mathrm{i} 1 / 121-126$ 